\title{
First record of Peckia (Sarcodexia) lambens \\ (Wiedemann, 1830) (Diptera: Sarcophagidae) parasitizing Spodoptera frugiperda (Smith, 1797) (Lepidoptera: Noctuidae) in Brazil
}

\author{
Primeiro registro de Peckia (Sarcodexia) lambens (Wiedemann, 1830) \\ (Diptera: Sarcophagidae) parasitando Spodoptera frugiperda (Smith, 1797) \\ (Lepidoptera: Noctuidae) no Brasil
}

\section{Ronaldo Toma ${ }^{\text {* }}$, Antonia Roel², Regiane Miranda²}

\begin{abstract}
Collections of larvae of Spodoptera frugiperda (Smith, 1797) (Lepidoptera: Noctuidae) carried out in the field in three localities in the city of Campo Grande, Mato Grosso do Sul, Brazil, from October 2012 to March 2014, recorded the presence of three species of Diptera parasitizing Spodoptera frugiperda: two species of Tachinidae, Achytas incertus (Macquart, 1851) and Winthemia trinitatis Thompson, 1963, and one species of Sarcophagidae, Peckia (Sarcodexia) lambens (Wiedemann, 1830). The latter is identified for the first time parasitizing $S$. frugiperda in Brazil.
\end{abstract}

KEYWORDS: agroecosystem; biological control; fall armyworm caterpillar; parasitoid.
RESUMO: Coletas de larvas de Spodoptera frugiperda (Smith, 1797) (Lepidoptera: |Noctuidae) realizadas no campo em três localidades da cidade de Campo Grande, Mato Grosso do Sul, Brasil, entre outubro de 2012 e março de 2014, registraram a presença de três espécies de Diptera como parasitoide de $S$. frugiperda: duas espécies de Tachinidae, Archytas incertus (Macquart, 1851) e Winthemia trinitatis Thompson, 1963, e uma espécie de Sarcophagidae, Peckia (Sarcodexia) lambens (Wiedemann 1830), sendo esta identificada pela primeira vez no país como parasitoide larval de $S$. frugiperda.

PALAVRAS-CHAVE: agroecosistema; controle biológico; lagarta-do-cartucho do milho; parasitoide. 
BUENAVENTURA; PAPE (2013) considered Peckia as a senior synonym of Sarcodexia, maintained the latter as a valid subgenus and redefined the new generic combination Peckia (Sarcodexia) lambens (Wiedemann, 1830). This species, ranging from the southern United States to Argentina (LOPES; LEITE, 1989), is a nonspecific parasite and has been recorded parasitizing birds (FESSL et al., 2001), mollusks (COUPLAND; BAKER, 2004), scorpions (TOWNSEND, 1893) and insects (HOFFMANN, 1927), being documented as myiasis-causing fly in some species of vertebrates (HAGMAN et al., 2005), including men (FERNANDES et al., 2009). This species has also been recorded as host of other parasitic insects (MARCHIORI et al., 2007).

Spodoptera frugiperda (Smith, 1797) is the major pest of maize crops in Brazil and the Americas. Intense infestation of fall armyworm larvae can cause significant losses in grain production. According to VALICENTE; TUELHER (2009), the management of this pest has been done basically with use of chemical insecticides.

MOLINA-OCHOA et al. (2003) recorded the following species of Sarcophagidae as parasitizing $S$. frugiperda: Helicobia morionella Aldrich, 1930 from Honduras and Nicaragua; Ravinia assidua (Walker, 1852) and Bercaea cruentata (Meigen, 1826) (as Sarcophaga georgina Wiedemann, 1830) from the United States; $P$. (S.) lambens from the Lesser Antilles and Honduras (as Sarcodexia lambens and Sarcodexia sternodontis Townsend, 1892, respectively); and Sarcophaga sp. from Venezuela and the United States.

In tropical systems, despite their great biodiversity, there is a lack of basic studies on taxonomy of insect pests and their natural enemies (MOLINA-OCHOA et al., 2003). The identification of the organisms associated

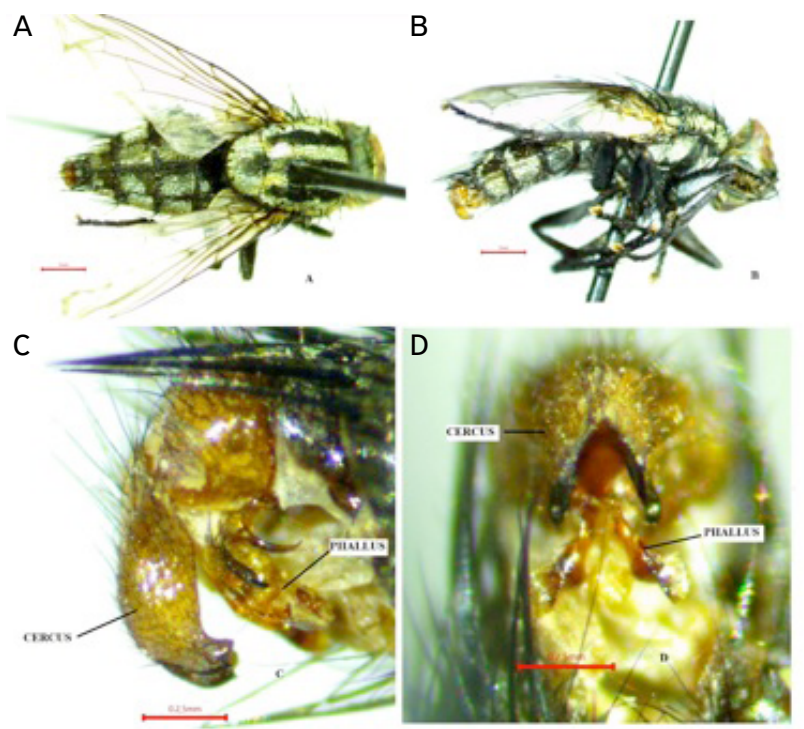

Figure 1. Peckia (S.) lambens (A) and (B), male habitus, dorsal and lateral views; $(C)$ terminalia in lateral view; $(D)$ teminalia in ventral view. with an agroecosystem is the first step in pest management (PRATISSOLI et al., 2010). Since the biodiversity may vary in different agroecosystems and it can be used to improve pest management (ALTIERI; NICHOLLS, 2004), it justifies the importance of the first record of $P$. (S.) lambens parasitizing $S$. frugiperda in the state of Mato Grosso do Sul, Brazil.

From October 2012 to March 2014, we collected eight larval samples of $S$. frugiperda in maize crops in three localities in the city of Campo Grande, state of Mato Grosso do Sul, Brazil: in the maize research field belonging to "Agência de Desenvolvimento Agrícola e Extensão Rural-AGRAER", in the Universidade Católica Dom Bosco campus (UCDB), and in a farm near the District of Rochedinho.

Fall armyworm larvae collected in the field were taken to the Entomological Laboratory of the UCDB, where they were separated individually within test tubes (diameter 2.5 $\mathrm{cm} \times 8.5 \mathrm{~cm}$ high) and bred with artificial diets, following GREENE et al. (1976). Adult tachinids were identified according to GUIMARÁES (1961) and COELHO et al. (1989), and the single specimen of Sarcophagidae was identified according to BUENAVENTURA; PAPE (2013) and CARVALHO; MELLO-PATIU (2008). Vouchers will be housed in the Zoological Collection of the Universidade Federal de Mato Grosso do Sul (UFMS) and in the Diptera Collection of the Museum of Zoology of the Universidade de São Paulo (MZUSP).

We collected 853 fall armyworm larvae of which eight percent were parasitized by three species of Diptera: two species of Tachinidae, Archytas incertus (Macquart, 1851) (61 specimens); Winthemia trinitatis Thompson, 1963 (seven specimens); and one species of Sarcophagidae, $P$. (S.) lambens (one specimen).

Achytas incertus and W. trinitatis have been recorded parasitizing $S$. frugiperda in maize crops in Brazil (MOLINAOCHOA et al., 2003). Studies on their biology and their interspecific relationship with $S$. frugiperda can be found in several works (MILWARD-DE-AZEVEDO et al., 1991; ANDRADE et al., 2008; SILVA et al., 2010), suggesting the potential use of these species in the biological control of the fall armyworm larvae in pest management.

Peckia (S.) lambens (Fig. 1) differs from these two species of Tachinidae by having the abdominal sternites exposed and overlapping the tergite margins, notopleuron with more than two setae and subscutellum not well-developed. Since this species shows intraspecific variation in its thoracic and abdominal chaetotaxy, it is important to confirm the identification by examination of the male genitalia.

Peckia (S.) lambens is known as parasitizing many Lepidoptera pest, Alabama argillaceae (Hübner, 1823), Oiketicus kirbyi (Gulding, 1827), Mocis latipes (Guenée, 1852), Diatrea saccharalis (Fabricius, 1794) (BLANCHARD, 1963). Although $P$. (S.) lambens is considered a facultative 
parasitoid (COUPLAND; BAKER, 2004), it was one of the main larval and pupal parasitoids of Hylesia metabus (Cramer, 1775) in Venezuela (HERNÁNDEZ et al., 2009). Peckia (S.) lambens parasitizing S. frugiperda have been recorded from the Lesser Antilles (FENNAH, 1947) and Honduras (MAES, 1989; CAVE, 1993), but there is no record of this parasitism from Brazil. The identification of the potential components which may interact in the larval control of $S$. frugiperda is important, and the record of parasitism of $S$. frugiperda by $P$. (S.) lambens in the state of Mato Grosso do Sul adds new information to this regional agroecosystem.

\section{ACKNOWLEDGMENTS}

The first author thanks Evelyn Ana Cafure (Escola Técnica do SUS-MS- ETSUS) and Gustavo Graciolli (Universidade Federal do Mato Grosso do Sul - UFMS) for logistic support and the later, and Dr. Zoraida Fernández (Fiocruz-MS) and Kenji Toma for suggestions to the manuscript. The second author is grateful for the financial support from the Ministerio da Ciência, Tecnologia, Inovações e Comunicações (MCTI); the Conselho Nacional de Desenvolvimento Científico e Tecnológico (CNPq); the Instituto Nacional de Áreas Úmidas (INAU), (704792/2009 edital MCTI/CNPq 015/2008).

| | | | | | | | | | | | | | | | | | | | | | | | | | | | | | | | | | | | | | | | | | | | | | | | | | | | | | | | | | | | | | | | | | | | | | | | | | | | | | | | | | | | | | | | | | | | | | | | | | | | | | | | | | | | | | | | | | | | | | | | | | | | | | | | | | | | | | | | | | | | | | | | | | | | | | | | | | | | | | | | | | | | | | | | | | | | | | | | | | | | | | | | | | | | | | | | | | | | | | | | | | | | | | REFERENCES

ALTIERI, M.A.; NICHOLLS, C.I. Biodiversity and Pest Management in Agroecosystems. New York: Haworth Press, 2004. 236p.

ANDRADE, P.P.; CRUZ, I.; FERREIRA, T.E.; CASTRO, A.L.G. Aspectos biológicos de Winthemia trinitatis Thompson e viabilidade do parasitismo sobre a lagarta-do-cartucho do milho Spodoptera frugiperda. In: CONGRESSO NACIONAL DE MILHO E SORGO, 27., SIMPÓSIO BRASILEIRO SOBRE A LAGARTA-DO-CARTUCHO, 3., 2008. Anais... Londrina: IAPAR; Sete Lagoas: Embrapa Milho e Sorgo, 2008. Available from: <https://www.embrapa. br/busca-de-publicacoes/-/publicacao/491221/aspectosbiologicos-do-diptero-winthemia-trinitatis-thompson-eviabilidade-do-parasitismo-sobre-a-lagarta-do-cartucho-domilho-spodoptera-frugiperda>. Accessed on: 21 abr. 2016.

BLANCHARD, E.E. Dípteros parásitos de Noctuidae argentines. Revista de Investigación Agrícola, Buenos Aires, v.17, n.2, p.129-254, 1963.

BUENAVENTURA, E.; PAPE, T. Revision of the New World genus Peckia Robineau-Desvoidy (Diptera, Sarcophagidae). Zootaxa, Auckland, v.3622, n.1, p.1-87, 2013.

CARVALHO, C.J.B.; MELLO-PATIU, C.A. Key to the adults of the most common forensic species of Diptera in South America. Revista Brasileira de Entomologia, Curitiba, v.52, n.3, p.390-406, 2008.

CAVE, R.D. Parasitoides larvales y pupales de Spodoptera frugiperda (Smith) (Lepidoptera: Noctuidae) en Centro América con una clave para las especies encontradas en Honduras. Ceiba, Tegucigalpa, v. 31, p. 33-56, 1993.

COELHO, S.M.P.; CARVALHO, C.J.B.; GUIMARÃES, J.H. Chave e sinonímias para as espécies sul-americanas de Winthemia RobineauDesvoidy (Diptera, Tachinidae) com descrição de três espécies novas. Revista brasileira de Zoologia, Curitiba, v.6, p.271-296, 1989.

COUPLAND, J.B.; BAKER, G.M. Diptera as Predators and Parasitoids of Terrestrial Gastropods, with Enphasis on Phoridae, Calliphoridae, Sarcophagidae, Muscidae and Fanniidae. In: BARKER, G.M. Natural Enemies of Terrestrial Molluscs. Wallingford: CABI Publishing, 2004. 644p. chap.3.
FENNAH, R.G. The insect pests of food-crops in the Lesser Antilles. St. George's, Grenada, B.W.I: Department of Agriculture for the Windward Islands, 1947. 207p.

FERNANDES, L.F.; PIMENTA, F.C.; FERNANDES, F.F. First report of human myiasis in Goiás State, Brazil: frequency of different types of myiasis, their various etiological agents, and associated factors. Journal of Parasitology, v.95, n. 1, p.32-38, 2009.

FESSL, B.; COURI, M.S.; TEBBICH, S. Philornis downsi Dodge \& Aitken, new to the Galapagos Islands (Diptera, Muscidae). Studia dipterologica, Halle (Saale), v.8, p.317-322, 2001.

GREENE, G.L.; LEPPLA, N.C.; DICKERSON, W.A. Velvetbean caterpillar: a rearing procedure and artificial medium. Journal of Economic Entomology, Annapolis, v.69, n.4, p.487-488, 1976.

GUIMARÃES, J.H. Segunda contribuição ao conhecimento do gênero Archytas Jaennecke, 1867 (Dipteara, Tachinidae). Memórias do Instituto Oswaldo Cruz, Rio de Janeiro, v.59, n.2, p.163-179, 1961.

HAGMAN, M.; PAPE, T.; SCHULTE, R. Flesh fly myiasis (Diptera, Sarcophagidae) in Peruvian poison frog genus Epipedobates (Anura, Dendrobatidae). Phyllomedusa, Piracicaba, v.4, n.1, p.69-73, 2005.

HERNÁNDEZ, J.V.; OSBORN, F.; HERRERA, F.; LIENDOBARANDIARAN, C.V.; PEROZO, J.; VELÁSQUEZ, D. Parasitoides Larva-Pupa de Hylesia metabus Cramer (Lepidoptera: Saturniidae) en la Región Nororiental de Venezuela: un Caso de Control Biológico Natural. Neotropical Entomology, Londrina, v.38, n.2, p.243-250, 2009.

HOFFMANN, W.A. Damage to potato by Pycnoscelus surinamensis. Journal of Economic Entomology, Annapolis, v.20, p.237, 1927.

LOPES, H.S.; LEITE, A.C.R. Morphology of the egg of Sarcodexia lambens (Diptera: Sarcophagidae). Memórias do Instituto Oswaldo Cruz, Rio de Janeiro, v.84, n.4, p.497-500, 1989. 
MAES, J.M. Catálogo de los insectos controladores biológicos en Nicaragua. Vol. III. Insectos Parasitoides. Revista Nicaraguense de Entomologia, León, n.10, p.1-138, 1989.

MARCHIORI, C.H.; LELES, A.S.; CARVALHO, S.A.; RODRIGUES, R.F. Parasitóides de dípteros Muscóides coletados no matadouro Alvorada em Itumbiara, sul de Goiás, Brasil. Revista Brasileira de Parasitologia Veterinária, Jaboticabal, v.16, n.4, p.235-237, 2007.

MILWARD-DE-AZEVEDO, E.M.V.; PARRA, J.R.P.; GUIMARÃES, J.H.; ALMEIDA, R.P. Aspectos da biologia de Archytas incertus (Diptera, Tachinidae) e de suas inter-relações com Spodoptera frugiperda (Lepidoptera, Noctuidae). 1 Metodologia de criação e determinação do instar mais adequado para a produção do parasitoide. Revisto Brasileira de Entomologia, São Paulo, v.35, n.3, p.485-497, 1991.

MOLINA-OCHOA, J.; CARPENTER, J.E.; HEINRICHS, E.A.H.; FOSTER, J. Parasitoids and parasites of Spodoptera frugiperda (Lepidoptera: Noctuidae) in the Americas and Caribbean Basin: an inventory. Florida Entomologist, Lutz, v.86, n.3, p.254-289, 2003.
PRATISSOLI, D.; GRECCO, E.D.; NIHEI, S.S.; POLANCZYK, R.A.; CELESTINO, F.N.; CARVALHO, J.R.; BARBOSA, W.F. Ocorrência de Lixophaga sp. (Diptera: Tachinidae) parasitando lagartas de Diaphania nitidalis (L.) (Lepidoptera: Crambidae) em Cucurbita moschata no Brasil. Arquivos do Instituto Biológico, São Paulo, v.77, n.4, p.719-721, 2010.

SILVA, R.B.; CRUZ, I.; FIGUEIREDO, M.L.C.; TAVARES, W.S.; CASTRO, A.L.G.; SANTOS, C.V.; FIGUEIREDO, J.R. Parasitismo de Winthemia trinitatis Thompson (Diptera: Tachinidae) sobre Lagartas de Spodoptera frugiperda (J. E. Smith) (Lepidoptera: Noctuidae). In: CONGRESSO NACIONAL DE MILHO E SORGO, 28. Anais... Goiânia: Associação Brasileira de Milho e Sorgo, 2010.

TOWNSEND, C.H.T. A scorpion parasite. Journal of the Institute of Jamaica, Kingston, v.1, p.221, 1893.

VALICENTE, F.H.; TUELHER, E.S. Controle biológico da lagarta do cartucho, Spodoptera frugiperda, com baculovírus. Circular Técnica, Sete Lagoas, n. 1 14, p.1-14, 2009. 